\title{
Does Macroeconomic Indicators Influence Stock Price Behavior? Evidence from Nigerian Stock Market
}

\author{
Peter Ego Ayunku \\ Department Of Banking, Finance And Insurance \\ Niger Delta University, Wilberforce Island Yenagoa, Bayelsa State \\ Email: Peterayunku@Yahoo.Com
}

Received: June 14, 2019 Accepted: July 18, 2019 Published: September 26, 2019

doi:10.5296/ifb.v6i2.14928 URL: http://dx.doi.org/10.5296/ifb.v6i2.14928

\begin{abstract}
This paper investigate whether macroeconomics indicators influences stock price behavior in Nigerian stock market, using an annual time series data spanning from 1985-2015. The study employed some econometric tools such as Augmented Dicker Fuller (ADF) Unit Root test, Johansen's co integration test, Vector Error Correction Model (VECM) to analyze the variables of interest. The study found out that Money Supply (MS) has an inverse but statistically significant influence on stock prices in Nigerian stock market also Treasury Bill Rate (TBR) has an inverse and statistically insignificant influence on stock market prices. While on the other hand, Market Capitalization (MCAP) has a positive and statistically significant influence on stock prices while Exchange Rate (EXR) has positive but statistically insignificant relationship with stock prices in the Nigerian Stock Market. In view of the above, the study recommends amongst others that monetary authorities should try as much as possible to implement sound macroeconomic policies that would enhance stock market growth and development in Nigeria.
\end{abstract}

Keywords: Market Capitalization, Stock Market, Financial Intermediation, Money Supply and Random Walk 


\section{Introduction}

The stock market plays a major role in financial intermediation in both developed and developing countries by channeling idle funds from surplus to deficit units in the economy. (Adaramola, 2012).

The Nigerian stock exchange which was incorporated in 1960 was saddle with the primary objective to create an appropriate mechanism for capital formation and the efficient allocation of resources through the maintenance of fair prices for its securities traded in the Nigerian stock market.

In economics the prices of goods and services are largely determined by the forces of demand and supply. But in corporate finance there are other factors that influences or determined the stock price in the stock market, which include but not limited to the following, dividend growth rate, earning growth rate, volume of trade, money supply, interest rates and inflation rate.

Ighodaro and Okiakhi (2013) argued that prices of stocks in the capital market are determined by some macroeconomic variables such as inflation rate, exchange rate, money supply and even manufacturing.

The most basic factors according to Al-Shubiri (2010) that influences prices of equity are demand and supply factors, and that if most people start buying, then prices move up and if people start selling prices go down. He stressed that government policies, firms and industry's performance and potentials have effects on demand behavior of investors, both in the primary and secondary markets.

Malaolu, Ogbuabor and Orji (2013) noted that stock prices all over the world including Nigeria is characterized by upward and downward movements of prices.

It has been asserted that the stock market of any country in the world is like a heartbeat depending on various circumstances and that the market goes either up or down which in the financial terms is referred to as a bull market and bear markets respectively. The stock market is said to be bull when price of stock goes up, which on the other hand, the market is said to be bearish when the stock market prices are moving or trending downwards. The stock market is a segment of the capital market were investment in stocks involves buying and selling and whose prices increases, or decreases and could remain unchanged for a period of time.

The sustained macro stability supported the Nigerian Stock Exchange to record another consecutive quarter growth in Q3, 2017. Gains in the equity market saw the Nigerian Stock Exchange as the market capitalization climbed to N19.62 trillion ( $\$ 64.16$ billion) representing a 18.73\% increase from N16.52trillion (54.4 billion) in Q3, 2016. (NSE, 2017).

Despite price losses that outweighed the gains, equity transactions on the Nigerian Stock Exchange closed on a positive note as most highly capitalized stock recorded price appreciation, causing the All Share Index (ASI) to increase marginally by 0.1 percent. The market capitalization of listed equity inched up marginally by $\mathrm{N} 2$ billion or 0.016 percent to 
N12.614 trillion from 12.612 trillion reported previously. The ASI also rose to $36,645.65$ points from 36,641.52 traded (NSE, 2017).

This study was therefore, carried out as the results of previous studies on the above had been inconclusive. Thus, the study is under taken so as to fill the research gap.

The board objective of this study is to investigate whether macroeconomic indicators influences stock price behavior in Nigerian stock market. The rest of the paper is organized as follows; section two, provides the review of related literature, section three, deals on the methodology while section four discusses the empirical results and section 5 concludes the paper and makes some recommendations.

\section{Review of Relevant Related Literature}

The issue of whether macroeconomic indicators influences stock price behavior has attracted researchers and scholars in recent times.

Adeniji (2015) study the link between stock market price volatility and macroeconomic variables in Nigeria. The study used monthly data for the period of 1990-2014 and employed GARCH (1.1) models and the relationship between stock market prices volatility and macroeconomic volatilities was examined using bi-variate and multivariate VAR Granger Causality tests as well as regression analysis. The results were not far from the view of previous studies as only three out of the five macroeconomic variables have a relationship with stock market prices volatility, he found that volatility in GDP, inflation and money supply were found to granger cause and were not significantly related to stock market prices volatility, and that only volatility in interest rate and exchange rate does granger cause stock market prices volatility.

Shawfari, Salem, Hussain and Hawariyuni, (2015) examined the long-term equilibrium between South Africa's stock index and selected macroeconomic variables using vector error correction models (VECM) the result indicates that industrial production is the most important determinant of stock market price, the result suggest that South Africa stock market is highly sensitive to the country's industrial production.

They found out that money supply, inflation and exchange rates are other determinants of South Africa's stock index but to a lesser extent than industrial production. The implication of their study is that any changes in the macroeconomic policy should take into consideration the impact of such changes on the stock market.

Inegbedion (2012) examined the macroeconomic determinants of stock price behavior in the Nigerian stock market, using some macroeconomic variables such as interest rate, inflation rate and exchange rate whether it affect stock price movements. Unit root test was conducted to test for stationary as well as to determine the degree of integration. The data were analyze by using Ordinary Least Square (OLS) and cochran-orcult autoregressive model of order 2AR (2) and the results of the study showed that some macroeconomic variables significantly affect stock price movements and thus affect the stability of the Nigerian capital market.

Arshad, Arshaad, Yousaf and Jamil (2015), Investigated the determinants of share prices of 
listed commercial banks in Karachi stock exchange over a period of 2007-2013, using linear multiple regression analysis. The results indicate that earning per share has more influence on share prices and has positive and significant relationship with share prices, book to market value ratio and interest rate also have significant but negative relationship with share prices while other variables such as gross domestic product, price earnings ratio, dividend per share, leverage have no relationship with share prices.

Muhanmad, and Durash, (2011) studied the individual investor behavior and stock prices in Karachi stock Exchange (KSE) using some variables such as earning per share, dividend yield, foreign direct investment, and gross domestic product growth rate with a sample of 35 firm for period of $2001-2008$, using multiple regression analysis and the results show that the influencing variables have a significant impact on Karachi Stock Exchange (KSE).

Fadiran and Olowookere(2016), examined the determinants of share prices and their relative importance on the Nigerian stock exchange for the period 2000-2011 using generalized least square and stepwise regression estimation techniques to evaluate the panel model at $5 \%$ level of statistical significance. The results revealed that the firm performance and macroeconomic condition are major determinants of share price on Nigerian stock exchange (NSE).

Osaze and Nosakhare (2014). Examines the relationship between stock price volatility and few macroeconomic variables such as inflation rate, exchange rate, (GDP) and interest rate for the period 1980-2011. They used securitized autoregressive conditional heteroskedasticity $(\mathrm{GARCH})$ model and the finding of the study showed that stock prices in Nigeria are volatile and that past information in the market have effect on stock price volatility in Nigeria. The study also showed that interest rate and exchange rate have a weak effect on stock price volatility while inflation rate is the main determinant of stock price volatility in Nigeria. The study also shows that interest rate and exchange rate have a weak effect on stock price volatility in Nigeria. The authors recommended that inflation should be targeted as the main monetary policy aimed at directing the stock market.

Umar and Ishaik (2009) examine the macroeconomic variable that are responsible for share price fluctuation in Nigeria for the period 1980-2006, using multiple regression to analyzed the data. The result showed that inflation, money supply, total deficits, under of industrial production, interest rate and GDP influence stock prices.

Also, Inyaimaland Ozouli (2015) examine the relationship between earning per share and market price of ordinary shares in Nigeria banking industry for the 2004-2013, using Ordinary Least Square (OLS) method and the results revealed that earning per share significantly and positively influence the market price of ordinary shares. They also observed that earning per share granger causes market price of ordinary shares and their characteristics are sustainable in the long run in Nigeria banking sector.

Ramdam (2016) studied the effect of macroeconomic factors on the movements of stock prices of Jordanian industrial companies listed in Amman Stock Exchange (ASE) for the period 2000-2014, using multiple least square regression method. The result showed significant negative effect of two of the macroeconomic factors such as interest and inflation 
rates on the movement of the Jordanian industrial company's stock prices and found out that the effect of money supply and GDP on the movement of stock price were significantly positive.

In a similar Vein and Joshi (2017) examine the long run and the short run relationship between stock prices and a set of macroeconomic variables for India economy using annual data spanning from 1979-2014. The long run relationship was examined by using the ARDL bounds testing approach to co-integration, also WECM method was used to test the short run and long run causality and variance decomposition was used to predict the long run exogenous shock of the variables.

The results confirm a long run relationship among the variables and evidence suggests that economic growth, inflation and exchange rate influence stock prices positively.

While crude oil price influences the stock prices negatively. This implies that increase in oil prices induces inflationary expectations in the mind of investors and stock prices are adversely affected. The result of VECM indicates that short run and long run in directional causality running from economic growth and FDI to stock prices in India. The result of variance decomposition shocks indicate that stock market development in India is mostly explained by its own shocks. They therefore recommended that government should take steps to control the crude oil price in India and investors' confidence has to be gained by boosting the economic growth of the economy through appropriate policy tools involved with special focus on independent research.

Nidhi and Kamini (2013) investigate the factors that influence stock prices in the context of National Stock Exchange (NSE) 100 companies. A sample of 95 companies was selected for the period 2007-2012, using linear regression model and the results indicate that the firm's book value, earning per share and price earnings ratio are having a significant positive association with firm's stock price while dividend yield was having a significant inverse association with the market price of the firm's stock.

Nicoya (2003) in a study examines the relative contributions of stock market volatility on economic growth in Nigeria for the period 1980 -2010, using Exponential Generalized Autoregressive Conditional Heteroskedasticity (EGARCH) techniques and found that volatility of stock is quite persistent in Nigeria and that this might distort growth of the economy. He therefore recommend that for the stock market to be less volatile, Securities and Exchange Commission (SEC) should be strengthened both in terms of number of man power and quality of the professionals involved with special focus on independent research.

Further,Lawaland Okunola (2012) examined stock prices, stock market operations and economic growth in Nigeria, using time series data from 1980-2010. They used granger causality modeling to test the direction of the granger relationship among the variables. The result showed that present value of stock price adjusted rapidly to changes in interest rate, inflation rate, exchange rate, broad moneysupply, gross domestic product, market capitalization and volume of transaction of the Nigeria stock exchange. And that the lagged value of error correction model given as $23.9 \%$ indicates a feedback of or an adjustment of 
$23.9 \%$ from the previous period disequilibrium of the present level of stock price in the determination of causality between the past level of stock price and the present level and past level of the explanatory variables and that the activities of the stock market are statistically significant with the stock prices and economic growth.

Maloalu, Ogbuabor and Orji (2003) conducted a study on the determinant of stock price movement in Nigeria, using detailed econometric framework in order to provide the foundation for evidencebased policies. Both the long-run and short run dynamic relationship between the macroeconomic variables we reanalyzed with time series data that spanned from 1985-2010 using the Engle-Grangers two steps co-integration test. They established that there was no co-integration between the variables indicating an absence of long run relationship. The result of the regression further indicates that monetary policy variables real exchange rate, real interest rate, money supply as well as political instability are not determinant of stock price movement in Nigeria, however inflation was found to be a major determinant of stock price movement.

Kilati, Zablonand Maithya (2015) studied the existence of influence of some selected macroeconomic variables of foreign exchange rate, interest rate and inflation rate on share price the fluctuations, using weight average monthly data for the period 2008-2012 for companies listed on the Nairobi securities exchange in Kenya. The result provides important implications for monetary policy, risk management practices, financial securities valuation and government policy towards financial markets.

They found out those stock prices fluctuations are predominantly due to the selected macroeconomic variables.

Adaramola (2011) investigated the impact of macroeconomic indicators on stock prices in Nigeria, using secondary data on stock prices of some selected firms for the period 1985-2009. The main economic variable used in the study were Money Supply (BRDM) Interest Rate (INTR), Exchange Rate (ECHR) Inflation Rate (INF), Oil Price (OIL) and Gross Domestic Product(GDP) using pooled \& panel data to examine the variables and the findings revealed that the macro economic variables have varying significant impact on stock prices of individual firms in Nigeria and that apart from inflation rate and money supply, all other variables have significant impact on stock prices in Nigeria.

Similarly, Hamadan andYusnidah (2013) examine the impact of macroeconomic indicators such as inflation, interest rate, money supply, oil prices and unemployment rate on Kuwait-stock exchange, using VAR model to analyze the variable for the period from 2001 -2010 on a monthly basis and found a positive association between inflation, money supply and oil price in 1-month time and stock return, while there was a negative relationship between interest rate in 1-month time and stock return in Kuwait stock market and that there was a positive relationship between interest rate in 2-month time and return. Finally, there was a negative relationship between inflation, money supply and oil prices in 2- month time and stock return in Kuwait stock market.

Also, Muritala, Taiwo and Olowookere (2012) study the impact of crude oil price, stock price 
and some selected macroeconomics variables on the growth of Nigeria economy from 1980-2010 using Johansen integration, unit root test and error correction model and it was found that crude oil price, stock price and exchange rate have significant influence on the growth of the Nigeria economy. The study therefore recommended that central bank should manage the dwindling nature of the interest rate to ensure transparency and accountability in the stock exchange market to boost the confidence of the investors and further as a matter of urgency diversity Nigeria economy from oil reliance to gainful manufacturing so as to minimize negative effects of oil shock.

Ogunmuyiwa and Akinlo (2016) studied the impact of macroeconomic indicators on the stock market using static panel regression technique for sample of 50 quoted firm across eight (8) major sectors of the market, for the period 2007-2013. The results reveal the varying impact exist between the macroeconomic indicators and firm share returns in Nigeria and that inflation rate, interest rate and exchange rate are the major significant macroeconomic indicators driving firm share return in Nigeria.

Ayopo, Isola and Olukayode (2017). The used EGARCH estimation techniques to examine the impact of the systematic risk emanating from the macroeconomic on stock market volatility based on monthly data sourced from 1985-2013 on the Nigeria economy. The results showed that all the macroeconomic variables tested exert on stock market pricing and that the stock market pricing is most influenced are exchange rate volatility. The study thus, recommends that policy makers should pay close attention to innovations in the macroeconomic variables when formulating macroeconomic policy, and that market practitioners should calibrate volatility of macroeconomic variables in their portfolio decision making process.

The study is therefore, carried out to fill the research gab in the body of literature as most of the findings are inconsistent.

\section{Methodology}

\subsection{Research Design}

This study adopted ex-post factor research design. Onwumere (2005) opined that this type of research involves events that have already taken place and that the data already exist as no attempt is made to control or manipulate the variables. The data source for this study is secondary data and are all sourced from the Nigerian Stock Exchange (NSE) Central Bank of Nigeria (CBN) statistical bulletin and Nigerian Bureau for Statistic (NBS).This study employed some econometric statistical tools such as Augmented Dickey-Fuller (ADF) and Ordinary Least Square (OLS) multiple regression to analyze the relationship of the variables of interest.

The study uses all share index proxy as stock prices. This variable is an important measure of stock performance of all listed equities on the stock market or exchange, while other variables such as market capitalization, money supply, Treasury bill rate and exchange rate were used. These variables are all important variables as they influence stock prices on the stock market. 
Based on the above, the statistical model used to analyze the relationship between the variables are thus, specified as follows;

$Y=a+b_{1} x_{1}+b_{2} x_{2}+b_{3} x_{3}+b_{4} x_{4}+\varepsilon$

Where;

$\mathrm{Y}=$ Dependent variables All Share Index (ASI) proxy for stock prices

$\mathrm{x}_{1}=$ Market capitalization (MCAP)

$\mathrm{x}_{2}=$ Money Supply (MS)

$\mathrm{x}_{3}=$ Treasury Bill Rate (TBR)

$\mathrm{x}_{4}=$ Exchange Rate $(\mathrm{EXR})$

$\varepsilon=$ Error term

Equation 1 above can be further expressed to carry it's parameters as follows;

$A S I_{t}=\beta_{O}+\beta_{1} M C A P_{t}+\beta_{2} M S_{t}+\beta_{3} T B R_{t}+\beta_{4} E X R_{t}+\varepsilon$

Where;

$\mathrm{ASI}_{\mathrm{t}}=$ All Share Index proxy for stock prices at time $\mathrm{t}$

$\mathrm{MCAP}_{\mathrm{t}}=$ Market Capitalization at time $\mathrm{t}$

$\mathrm{MS}_{\mathrm{t}}=$ Money Supply at time $\mathrm{t}$

$\mathrm{TBR}_{\mathrm{t}}=$ Treasury Bill Rate at time $\mathrm{t}$

EXR $_{\mathrm{t}=\text { Exchange }}$ Rate at time $\mathrm{t}$

$\beta_{1} \beta_{4}$ are the coefficients to be estimated

$\beta_{0}=$ Intercept

$\varepsilon=$ error term

\section{Results and Discussions}

Table 1. The Augmented Dickey fuller (ADF) unit Root Test Results

\begin{tabular}{|c|c|c|c|c|c|}
\hline Series & $\begin{array}{l}\text { ADF Test } \\
\text { Statistics }\end{array}$ & $\begin{array}{l}5 \% \text { Critical } \\
\text { Values }\end{array}$ & $\begin{array}{l}\text { 10\% Critical } \\
\text { Values }\end{array}$ & $\begin{array}{l}\text { Order Of } \\
\text { Integration }\end{array}$ & Remarks \\
\hline ASI & -5.604523 & -1.952910 & -1.610011 & $1(1)$ & Stationery of $1^{\text {st }}$ diff \\
\hline YBR & -5.383270 & -1.953381 & -1.609798 & $1(1)$ & Stationery of $1^{\text {st }}$ diff \\
\hline MS & -9.619064 & -1.953381 & -1.609748 & $1(2)$ & Stationery of $2^{\text {nd }}$ diff \\
\hline EXR & -4.138031 & -1.952910 & -1.610011 & 1(1) & Stationery of $1^{\text {st }}$ diff \\
\hline MCAP & -5.067681 & -1.95210 & -1.610011 & 1(1) & Stationery of $1^{\text {st }}$ diff \\
\hline
\end{tabular}

Source: Eview output.

From Table 1 above the ADF unit root test results indicate that all the variables were stationary at order one except money supply that integrated at order two .All the ADF test 
statistics values were greater than $5 \%$ and $10 \%$ critical values respectively

Table 2. Descriptive statistics

\begin{tabular}{lccccc}
\hline & EXR & MS & MCAP & ASI & TBR \\
\hline Mean & 80.44146 & 4147.205 & 4277.542 & 14761.13 & 13.24581 \\
Median & 102.1052 & 878.4600 & 472.3000 & 8111.000 & 12.50000 \\
Maximum & 192.3000 & 18901.30 & 19077.40 & 57990.20 & 26.90000 \\
Minimum & 0.893800 & 22.30000 & 6.600000 & 127.3000 & 4.500000 \\
Std. Dev. & 64.71309 & 5899.600 & 6189.710 & 15018.90 & 4.995624 \\
Skewness & 0.009335 & 1.315527 & 1.206872 & 0.947383 & 0.873288 \\
Kurtosis & 1.330614 & 3.298993 & 2.959524 & 3.293225 & 4.222986 \\
Jarque-Bera & 3.600131 & 9.056962 & 7.527574 & 4.748321 & 5.872201 \\
Probability & 0.165288 & 0.010797 & 0.023196 & 0.093093 & 0.053072 \\
Sum & 2493.685 & 128563.3 & 132603.8 & 457595.0 & 410.6200 \\
Sum Sq. Dev. & 125633.5 & $1.04 \mathrm{E}+09$ & $1.15 \mathrm{E}+09$ & $6.77 \mathrm{E}+09$ & 748.6878 \\
Observations & 31 & 31 & 31 & 31 & 31 \\
\hline
\end{tabular}

Source: Eview Output.

From table 2 above ,the descriptive statistics of variables indicate that Exchange Rate(EXR) averages 80.44 and it ranges from 0.89 to 192.30 with std. deviation values of 64.71 ,skewness and kurtosis values of 0.009 and 1.33 respectively. The Money Supply (MS) has a mean value of 4147.20 and it also ranges from 22.3 to 18901 with std. deviation value of 5900.00, skewness and kurtosis values of 1.3 and 3.30 respectively. Market capitalization has an average of 4277.54 and it ranges from 6.6 to 19077.40 with a std. deviation of 6189.70 , while skewness and kurtosis values were 1.20 and 2.96 respectively.

All Share Index (ASI) and Treasury Bill Rate (TBR) averages 14761 and 13.24 and it also ranges from 127.30 to 57990.20 and 4.5 to 26.90 respectively. While its std. deviation stood at 15018.90 and 4.99 with skewness and kurtosis values of 0.95 and 0.87 and 3.29 and 4.22 respectively.

\subsection{Johansen Integration Test Results}

In order to test for cointegration among the variables, the study adopted Johansen (1988) cointegration test. Table 3 below presents Johansen's cointegration test results 


\section{Ml Macrothink}

Table 3. Johansen co integration test results

Date: $07 / 31 / 18$ Time: $20: 20$

Sample (adjusted): 19872015

Included observations: 29 after adjustments

Trend assumption: Linear deterministic trend

Series: ASI EXR MS MCAP TBR

Lags interval (in first differences): 1 to 1

Unrestricted Cointegration Rank Test (Trace)

\begin{tabular}{|c|c|c|c|c|}
\hline \multirow{3}{*}{$\begin{array}{l}\text { Hypothesized } \\
\text { No. of CE(s) } \\
\text { None * }\end{array}$} & \multicolumn{2}{|r|}{ Trace } & \multicolumn{2}{|l|}{0.05} \\
\hline & Eigenvalue & Statistic & Critical Val & Prob. ** \\
\hline & 0.799895 & 99.67572 & 69.81889 & 0.0000 \\
\hline At most $1 *$ & 0.525880 & 53.01732 & 47.85613 & 0.0151 \\
\hline At most $2 *$ & 0.489991 & 31.37474 & 29.79707 & 0.0326 \\
\hline At most 3 & 0.333545 & 11.84825 & 15.49471 & 0.1644 \\
\hline At most 4 & 0.002774 & 0.080560 & 3.841466 & 0.7765 \\
\hline
\end{tabular}

Trace test indicates 3 cointegratingeqn(s) at the 0.05 level

* denotes rejection of the hypothesis at the 0.05 level

**MacKinnon-Haug-Michelis (1999) p-values

Source : Eview output

Thus, Table 3 above report the results of Johansen's (1988) cointegration test, which circumvents the use of two step estimators and allow us to estimate and test for multiple cointegrating vectors. The trace statistics test indicates the existence of three (3) conintegrating equations at the 0.05 significant levels. The result suggests that the null hypotheses of no co integration among variables are rejected.

\subsection{Error Correction Model (ECM)}

The error correction Model (ECM) as developed by Engle and Granger (1987) is a means of reconciling the short run behavior of economic variables with its long run behavior. Table 3 below therefore reports the short run dynamics of the error correction model.

Table 4. Short run behavior of Error correction model (ECM) test results

Estimation of Short Run Dynamics: Error Correction Model (ECM)

Dependent Variable: D(ASI)

Method: Least Squares

Date: $07 / 31 / 18$ Time: $20: 37$

Sample (adjusted): 19862015

Included observations: 30 after adjustments

\begin{tabular}{lllll}
\hline Variable & Coefficient & Std. Error & t-Statistic & Prob. \\
\hline C & 820.6916 & 667.3563 & 1.229765 & 0.2307 \\
D(EXR) & 13.28497 & 33.79835 & 0.393066 & 0.6977 \\
D(MS) & -3.086413 & 0.600195 & -5.142352 & 0.0000 \\
D(MCAP) & 3.569880 & 0.230739 & 15.47149 & 0.0000 \\
D(TBR) & -46.43367 & 106.5779 & -0.435678 & 0.6670 \\
ECM(-1) & -0.496101 & 0.153699 & -3.227743 & 0.0036 \\
\hline R-squared & 0.918221 & Mean dependent var & 950.4983 \\
Adjusted R-squared & 0.901184 & S.D. dependent var & 8177.718 \\
S.E. of regression & 2570.669 & Akaike info criterion & 18.71858 \\
Sum squared resid & $1.59 E+08$ & Schwarz criterion & 18.99882 \\
Log likelihood & -274.7786 & Hannan-Quinn criter. & 18.80823 \\
F-statistic & 53.89485 & Durbin-Watson stat & 1.867026 \\
Prob(F-statistic) & 0.000000 & & &
\end{tabular}

Source: Eview Output. 
From the table 4 above the short run behavior of the error correction model (ECM) result indicates that money supply (MS) and market capitalization (MCAP) are statistically significant in the short and long run. But exchange rate and Treasury bill rates are not statistically significant in the short run but exchange rate is statistically significant in the long run.

From the above results, the coefficient of determination $\left(\mathrm{R}^{2}\right)$ value is 0.918221 , which implies that about $92 \%$ of the total variation in ASI is explained by changes in the explanatory variables. Thus $8 \%$ is unexplained largely due to the error term. On the whole the F-statistic values stood at 0.000000 meaning that the F-statistic is highly statistically significant at the $0.05 \%$ level of significance. The Durban Watson statistics value of 1.87 further indicates the model is adequate and of a high goodness of fit there is absence of serial autocorrelation. Also the coefficient of the error correction model as expected indicates the correct sign of -0.50 which means that the speed of adjustment from the short to the long run among the variables is $50 \%$ and was statistically significant at $0.05 \%$ level of significance.

The coefficient of MS and TBR has an inverse relationship with ASI, but MS was statistically significant at 5\% level of significance both in the short and long run. While EXR and MCAP had a positive influence on ASI but EXR was not statistically significant at $5 \%$ level of significance.

The findings are partially consistent with the studies by Adenitis (2015) that inflation and money supply were not found to granger cause and not statistically related to stock market prices volatility.

\section{Conclusion and Recommendations}

This paper empirically investigated whether macroeconomic indicators influences stock price behavior, using an annual time series data spanning from 1985 to 2015 . The study utilized some econometric tools such as Johansen's cointegration and error correction model to analyze the variables of interest and the results suggest that Money Supply (MS) and Treasury Bill Rate (TBR) has an inverse relationship with All Share Index (ASI) proxy for stock prices, but money supply was statistically significant at 5\% level of significance while treasury bill rate was not statistically significant. On the other hand, Exchange Rate (EXR) and Market Capitalization (MCAP) have a positive influence on stock prices in the Nigeria stock market, but Exchange Rate (EXR) was not statistically significant while Market Capitalization (MCAP) was significant at 5\% level of significance respectively.

In view of the above and based on the findings, the study recommends amongst others that;

- That monetary authority should try as much as possible to implement sound macroeconomic policies that would enhance the growth and development of Nigeria stock market.

- And that since market capitalization has a positive influence on stock prices, efforts should be geared towards maintaining a stable macroeconomic policies so as to enhance economic growth in Nigeria. 


\section{References}

Adaramola, A. O. (2011). The Impact of Macroeconomic Indicators on Stock Prices in Nigeria. Developing Countries Studies, 1(2), 1-14.

Adaramola, A. O. (2012). Oil Price Shocks and Stock Market Behavior: The Nigeria Experience. https://doi.org/10.1080/09765239.2012.11884948

Adenoid, S. O. (2015). An Empirical Investigation of the Relationship between Stock Market Prices Volatility and Macroeconomic Variables Volatility in Nigeria. European Journal of Academic Essays, 2(11), 1-12.

Al-Shubiri, F. N. (2010). Analysis the Determinants of Market Stock Price Movement: An Empirical Study of Jordanian. Commercial Banks. International Journal of Business and Management, 5(10), 137-147. https://doi.org/10.5539/ijbm.v5n10p137

Arshad, Z., Arshad, A. R., Yusuf, A., \& Jamil, S. (2015). Determinants of Share Prices ofListed Commercial Banks in Pakistan. IOSR Journal of Economics and Finance, 6(2), 56-64.

Ayopo, B. A., Isola, L. A., \& Olukayode, S. R. (2017). Stock Market Volatility: Does our Fundamentals Matters? Economics Studies Journal, (3), 33-42.

Engle, R. F., \& Granger, C. W. J. (1978).Cointegration and Error Correction: Representation Estimation and Testing. Economentrica, (55), 251-276. https://doi.org/10.2307/1913236

Fadiran, T. P., \& Olowookere, A. E. (2016). Determinants of Share Prices on the Nigeria's Stock Exchange. International Journal of Business and Applied Social Science, 2(7), 49-60.

Fama, E. F. (1965). Random Walks in Stock Market Prices Selected Papers No 16 Available www.chicagobboth.edu https://doi.org/10.2469/faj.v21.n5.55

Giri, A. K., \& Joshi, P. (2017). The Impact of Macroeconomic Indicators on Indian Stock Prices: An Empirical Analysis. Studies in Business and Economic, 12(1), 61-78. https://doi.org/10.1515/sbe-2017-0005

Hamdan, A. A., \& Yusnidah, I. (2013). The Effect of Macroeconomic Indicator on Stock Returns: Evidence from Kuwait Stock Market. American Journal of Economics, 3(50), 57-66.

Hamdan, I. Z. (2016). Macroeconomic Approach of the Determinants of Stock Price Movements in Jordan. Asian Journal of Finance and Accounting, 8(2), 60-69. https://doi.org/10.5296/ajfa.v8i2.8616

Ighodaro, C. A. U., \& Oriakhi, D. E. (2013). Macroeconomic Variables and the Nigeria Capital Market. Journal of Banking, CBN. 7(1), 71-94.

Inegbedion, H. E. (2012). Macroeconomics Determinants of Stock Price Changes: Empirical Evidence from Nigeria. India Journal of Finance, 6(2), 19-23.

Inyiamal, O. K., \& Ozauli, C. (2015). Does Earning Per Share Determine Market Price of Ordinary Share? Evidence from Nigeria Banking Sector. European Journal of Accounting 
Auditing and Finance Research, 3(7), 21-32.

Johansen, S. (1988). Statistical Analysis of Cointegration Vectors. Journal of Economics Dynamics and Control, (12), 231-254. https://doi.org/10.1016/0165-1889(88)90041-3

Kilati, E., Zablon, E., \& Maithya, H. (2015). Effect of Macroeconomic Variables on Stock Market Prices for the Companies Quoted on the Nairobi Securities Exchange in Kenya. International Journal of Sciences: Basic and Applied Research, 21(2), 235-263.

Lawal, N. A., \& Okumuola, O. E. (2012). Stock Prices, Stock Market Operations and Nigeria Economic Growth. A Granger Causality Modeling. Global Advanced Research Journal of Management and Business Studies, 1(10), 375-383.

Malaolu, V. A., Ogbuabor, J. E., \& Oriji, A. (2013). Determinants of Stock Price Movements in Nigeria. Evidence from Monetary Variables. Journal of Economics and Sustainable Development, 4(14), 61-66.

Muhammad, A., \& Durash, K. (2011). Factors Influencing the Individual Investor and Stock Prices Variation: Evidence from Karachi Stock Exchange.

Muritala, T., Taiwo, A., \& Otowookere, D. (2012). Crude Oil Price, Stock Price and Some Selected Macroeconomic Indicator Implications on the Growth of the Nigeria Economy.

Nidhi, M., \& Kamini, T. (2013). Determinants of Stock Prices: Empirical Evidence from NSE 100 companies. IRACST-International Journal of Research in Management and Technology, 3(3), 86-95.

NSE. (2017). Nigerian Stock Exchange Fact Book.

Nwidobie, B. M. (2014). The Random Walk Theory: An Empirical Test in the Nigerian Capital Market. Asian Economic and Financial Review, 4, 1840-1848.

Ogunmuyiwa, M. S., \& Akinlo, O. O. (2016). A Panel Data Analysis of the Impact of Macroeconomic Indicators on Firms Shares Performance in Nigeria. Euroeconomica, 35(2), 199-12.

Onakoya, A. B. (2013). Stock Market Volatility and Economic Growth in Nigeria. International Review of Management and Business Research, 2(1), 201-209.

Osaze, E. B. (2007). Capital Markets African and Global. The BookHouse Company Publishers, Lagos.

Osazee, G., \& Nosakhare, I. (2014). Macroeconomic Variables and Stock Price Volatility in Nigeria. Annals of the University of Petrosani, Economics, 14(1), 259-268.

Ouwurmere, J. U. J. (2005). Business and Economic Research Methods. Don-Vinton Ltd, Lagos.

Shawtari, F. A., Sallem, M. A., Hussian, H. I., \& Hawariyuni, W. (2015). Long Run Relationship between Macroeconomic Indicators and Stock Price. The Case of South Africa. Journal of Internet Banking and Commerce, S 2, 007. 
Udegbuham, R. I., \& Eriki, P. O. (2001). Inflation and Stock Price Behavior: Evidence from Nigeria Stock Market. Journal of financial Management and Analysis, XX(14), 1-10.

Umar, Grand Ishiak, O. I. (2009). Environmental Factors Influencing fluctuation of Share Prices on Nigeria Stock Exchange Market African Research Review. An International $\begin{array}{llll}\text { Multi-Disciplinary Journal, } & \text { Ethiopia, } & \text { 3(5), }\end{array}$ https://doi.org/10.4314/afrrev.v3i5.51152

\section{Copyrights}

Copyright for this article is retained by the author(s), with first publication rights granted to the journal.

This is an open-access article distributed under the terms and conditions of the Creative Commons Attribution license (http://creativecommons.org/licenses/by/4.0/). 